\title{
IS THE NEW PROCORE 20G DOUBLE FORWARD-BEVEL NEEDLE CAPABLE TO OBTAIN BETTER HISTOLOGICAL SAMPLES BY ENDOSCOPIC ULTRASOUND FOR DIAGNOSING SOLID PANCREATIC LESIONS?
}

\author{
A nova agulha ProCore 20G com bisel frontal duplo é capaz de obter melhores amostras histológicas por \\ ecoendoscopia no diagnóstico de lesões sólidas pancreáticas?
}

\author{
José Celso ARDENGH ${ }^{1,2 \odot}$, Vitor Ottoboni BRUNALDI ${ }^{1,2 \odot}$, Mariângela Ottoboni BRUNALDI ${ }^{2,3 \odot}$, Alberto \\ Facuri GASPAR ${ }^{1,20}$, Jorge Resende LOPES-JÚNIOR ${ }^{1,2}$, Ajith Kumar SANKARANKUTTY $^{1,2 \oplus}$, Rafael \\ KEMP ${ }^{1,2 \odot}$, José Sebastião dos SANTOS $1,2 \odot$
}

\begin{abstract}
Background: It is important to obtain representative histological samples of solid biliopancreatic lesions without a clear indication for resection. The role of new needles in such task is yet to be determined. Aim: To compare performance assessment between $20 \mathrm{G}$ double fine needle biopsy (FNB) and conventional 22G fine needle aspiration (FNA) needles for endoscopic ultrasound (EUS)-guided biopsy. Methods: This prospective study examined 20 patients who underwent the random puncture of solid pancreatic lesions with both needles and the analysis of tissue samples by a single pathologist. Results: The ProCore 20G FNB needle provided more adequate tissue samples (16 vs. 9, $p=0.039$ ) with better cellularity quantitative scores ( 11 vs. $5, p=0.002)$ and larger diameter of the histological sample $(1.51 \pm 1.3 \mathrm{~mm}$ vs. $0.94 \pm 0.55 \mathrm{~mm}, \mathrm{p}=0.032)$ than the $22 \mathrm{G}$ needle. The technical success, puncture difficulty, and sample bleeding were similar between groups. The sensitivity, specificity, and diagnostic accuracy were $88.9 \%, 100 \%$, and $90 \%$ and $77.8 \%$, $100 \%$, and $78.9 \%$ for the $20 \mathrm{G}$ and $22 \mathrm{G}$ needles, respectively. Conclusions: The samples obtained with the ProCore 20G FNB showed better histological parameters; although there was no difference in the diagnostic performance between the two needles, these findings may improve pathologist performance.
\end{abstract}

HEADINGS: Diagnosis. Endoscopic Ultrasound. Fine-Needle aspiration biopsy. Fine-needle biopsy. Pancreatic cancer.

\footnotetext{
RESUMO-Racional: As lesões sólidas pancreáticas não ressecáveis cirurgicamente demandam boa amostragem tecidual para definição histológica e condução oncológica. O papel das novas agulhas de ecopunção no aprimoramento diagnóstico ainda necessita elucidação. Objetivo: Comparar as biópsias guiadas por ecoendoscoopia com a nova agulha 20G de bisel frontal duplo (FNB) com a agulha de aspiração fina $22 \mathrm{G}$ convencional. Métodos: Este estudo prospectivo avaliou 20 pacientes submetidos à punção de lesões pancreáticas sólidas com ambas agulhas e envolveu análise de amostras teciduais por um único patologista. Resultados: A agulha FNB 20G forneceu amostras de tecido mais adequadas (16 vs. 9, $p=0,039)$ com melhores escores quantitativos de celularidade ( 11 vs. $5, p=0,002)$ e maior diâmetro máximo da amostra histológica $(1,51 \pm 1,3 \mathrm{~mm}$ vs. $0,94 \pm 0,55 \mathrm{~mm}, p=0,032)$ que a agulha 22G. O sucesso técnico, dificuldade de punção e sangramento da amostra foram semelhantes entre os grupos. A sensibilidade, especificidade e acurácia diagnóstica foram $88,9 \%, 100 \%$ e $90 \%$ e $77,8 \%, 100 \%$ e $78,9 \%$ para as agulhas $20 \mathrm{G}$ e $22 \mathrm{G}$, respectivamente. Conclusão: As amostras obtidas com a FNB 20G apresentaram melhores parâmetros histológicos, embora não tenha havido diferença no desempenho diagnóstico entre as duas agulhas.

DESCRITORES: Diagnóstico. Endossonografia. Biópsia. Neoplasias Pancreáticas. Patologia.
}

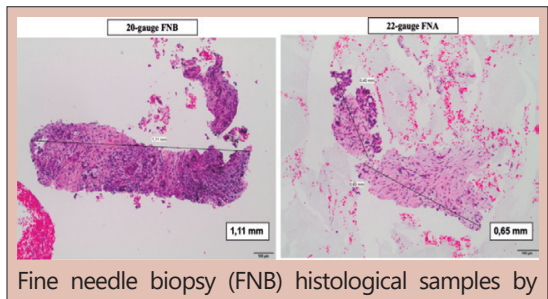
endoscopic ultrasound

\section{Central message}

The new ProCore $20 \mathrm{G}$ needle provides more adequate tissue samples but similar diagnostic profile compared to the standard 22G FNA needle.

\begin{tabular}{|l|}
\hline Perspective \\
\hline Increasing the adequacy of tissue samples without \\
increasing puncture difficulty and bleeding could \\
favor centers with less experienced pathologists. Also, \\
it could provide better rates of diagnostic punctures, \\
thus reducing false-negative results and expediting \\
histological confirmation. Therefore, defining the role \\
of new potentially better needles, such as the $20 \mathrm{G}$ \\
ProCore, in such task is of main importance.
\end{tabular}

From the 'Division of Gastrointestinal Surgery (Endoscopy Unit), Department of Surgery and Anatomy, Ribeirão Preto Medical School, University of São Paulo, São Paulo, Brazil; ${ }^{2}$ Hospital das Clínicas, Ribeirão Preto Medical School, University of São Paulo, São Paulo, Brazil; ${ }^{3}$ Department of Pathology and Forensic Medicine, Ribeirão Preto Medical School, University of São Paulo, São Paulo, Brazil

How to cite this article: Ardengh JC, Brunaldi VO, Brunaldi MO, Gaspar AF, Lopes-Júnior JR, Sankarankutty AK, Kemp R, dos-Santos JS. Is the new ProCore 20G double forward-bevel needle capable to obtain better histological samples by endoscopic ultrasound for diagnosing solid pancreatic lesions? ABCD Arq Bras Cir Dig. 2020;33(4):e1554. DOI: /10.1590/0102$672020200004 \mathrm{e} 1554$ 
INTRODUCTION

$\mathrm{O}$ btaining cells by endoscopic ultrasound-guided fine-needle aspiration (EUS-FNA) is crucial for the histological diagnosis of solid pancreatic lesions ${ }^{25}$ with no indication for surgical resection ${ }^{\mathbf{8}, 28}$. The sensitivity, specificity, positive predictive value (PPV), negative predictive value (NPV), and accuracy of detecting pancreatic carcinoma (PC) are 79-98\%, 71-100\%, 96-100\%, 33-85\%, and 82-98\%, respectively, ${ }^{17-19,21,23,24,26,29,30}$, while the false negative and false positive rates are $12-14 \%^{1,31}$ and $0-5 \%^{1,14,16,31}$, respectively. Therefore, efforts to improve the collection of tissue samples for histological diagnosis and additional molecular tests can increase the accuracy of the biopsy obtained by EUS and positively influence daily clinical practice, research, and treatment. Considering the FNA methodology, device positioning, analysis by a specialized pathologist, needle gauge, lesion characteristics and location, and the technical variables for obtaining and studying solid pancreatic lesion samples, can interfere with the diagnostic accuracy of EUS-FNA ${ }^{10,25}$. In this context, new needle biopsy (fine needle biopsy [FNB) devices that can collect tissue cores instead of just cytological samples can theoretically improve diagnostic accuracy without affecting the technique, costs, and occurrence of adverse events.

The diagnostic performance of EUS-FNA using the samples obtained with these needles was recently evaluated ${ }^{7,9}$, but different FNB types are available that have not yet been compared $^{13}$. The newly designed $20 \mathrm{G}$ double forward-bevel FNB needle (ProCore) is one of these new devices that aims to improve the diagnostic capacity of the histological samples obtained by EUS-FNA.

Recent meta-analyses that assessed the diagnostic capacity of the histological samples obtained did not include studies with the new $20 \mathrm{G}$ double forward-bevel FNB needle (ProCore) ${ }^{12,13}$.

Therefore, this study aimed to compare the performance of the $22 \mathrm{G}$ needle and the new $20 \mathrm{G}$ needle (ProCore) in obtaining the tissue sample and in the diagnosis of solid pancreatic tumors.

\section{METHODS}

\section{Study design}

This prospective randomized study was conducted at Hospital das Clínicas, Ribeirão Preto Medical School, University of São Paulo, Ribeirão Preto, São Paulo, Brazil), a public and tertiary teaching hospital, upon receiving approval from its research ethics committee (process number 6971-2018).

\section{Eligibility criteria}

Adult patients ( $>17$ years old) with solid pancreatic lesions referred for diagnosis by EUS-FNA, excluding those with cystic lesions, clinical instability, intractable coagulopathy (international normalized ratio $<1.5$ and/or thrombocytopenia $<50,000)$, previous pancreatic biopsy, and severe ascites as well as those who refused to sign the informed consent form.

\section{Randomization and allocation}

The randomization list was created using a system based on a computer program in the proportion of 1:131. The randomization list and allocation envelopes were defined before the first inclusion. Based on the list, a researcher uninvolved with the study prepared sealed sequential opaque envelopes that were opened upon confirmation of the patient's eligibility during the EUS assessment.

All patients were submitted to four needle passes (22G and 20G) with 10 back-and-forth movements during each pass and were allocated into two groups based on the needle type used first. Patients in group A underwent two punctures with a 22G FNA needle followed by two punctures with a 20G FNB needle, while those in group $B$ underwent two punctures with a $20 \mathrm{G}$ needle followed by two punctures with a $22 \mathrm{G}$ needle. The pathologist was aware of the type of needle used for the collection but was unaware of the allocation group.

\section{Procedures}

All patients underwent EUS under deep sedation with propofol. The standard biliopancreatic assessment was initially performed using a linear echoendoscope (Fujinon 530-UT or Pentax EG-3870UTK). Eligibility was confirmed after the collection of demographic and clinical data, results of previous imaging tests and EUS findings were reviewed, a researcher involved with the study opened the allocation envelope, and the EUS-guided punctures were performed. A 22G FNA needle (Expect; Boston Scientific, Marlborough, MA, USA) and a 20G FNB needle (Procore 20G, Cook Medical, Bloomington, IN, USA) were used.

The needle was passed through the lesion and an image was captured to confirm its correct positioning. Next, the stylet was completely removed and suction was performed with a 10 -cc syringe. The ventilation technique was also used to improve tissue sample collection ${ }^{35}$. After 10 back-and-forth movements, the needle was retracted and washed with saline to extract the sample collected in a $10 \%$ formalin vial to the block. As each vial represented a passage of the needle, each patient had four vials identified with needle type. An experienced endoscopist performed all procedures (JCA) and graded the puncture difficulty (1:none; 2:easy; 3:moderate; 4:difficult) and reported the macroscopic impression of the amount of tissue collected (1:little; 2:regular; 3:increased).

After the puncture, the endoscopist assessed the gastrointestinal tract for immediate adverse events (AEs). The patients were sent to the recovery room, observed for about $2 \mathrm{~h}$ after the procedure, and subsequently discharged if no $A E$ was detected and provided a phone number of the service for contact if needed. An outpatient visit was scheduled about one month after the procedure to examine the result and assess any late AEs. Early adverse events were defined as those starting within $48 \mathrm{~h}$ after the procedure and late events as those starting within $48 \mathrm{~h}$ to one month after the procedure.

\section{Histological assessment}

The samples were previously fixed in $10 \%$ formalin for 6-24 h. Fragments larger than $1 \mathrm{~mm}$ were processed with a standard paraffin block. Samples smaller than $1 \mathrm{~mm}$ were centrifuged (1.500 rpm) for $10 \mathrm{~min}$. The tissue sediment was collected in Eppendorf tubes containing $1.5 \mathrm{ml}$ of $3 \%$ agarose and then centrifuged again. The cell block immersed in agarose was cooled to $0.7^{\circ} \mathrm{C}$. After solidifying, the block was sectioned, placed in cassettes, and sent for standard histological assessment with paraffin inclusion ${ }^{5}$.

A specialized pathologist (MOB) assessed all samples. The cellularity and bleeding were assessed using validated objective scales. The cellularity was classified from 1 to 4 as follows: $1,<50$ cells; $2,50-100$ cells; $3,100-200$ cells; $4,>200$ diagnostic cells. Scores 3 and 4 were considered adequate for histological assessment ${ }^{27}$. The bleeding was graded as mild (scarce hemorrhagic cells), moderate (frequent hemorrhagic cells), or intense (frequent hemorrhagic cells and clots that impair the histological assessment). The cell groups were measured using the cellSens Micro Imaging Software (Olympus America Inc, Center Valley, PA, USA). The size of the largest histological nucleus was annotated for each pass and each needle for later comparison. 


\section{Gold standard for comparison}

In cases indicated for surgical resection, the histopathology of the resected sample was the diagnostic gold standard. For patients who did not undergo surgery, the final diagnosis of malignancy was provided by disease progression considering clinical deterioration, death, and/or images consistent with metastatic lesions after six months of follow-up. Similarly, the negative gold standard in cases of a negative histopathological diagnosis was a consistent clinical result and images after six months of follow-up. In addition to adenocarcinoma, pancreatic neuroendocrine tumors and mesenchymal neoplasms were also considered positive for malignancy.

\section{Endpoints}

The primary endpoint was the proportion of suitable samples obtained with each needle. The secondary end points included the endoscopist's impression of the tissue amount and puncture difficulty during EUS, larger cell group size, classification of bleeding in the histological assessment, and diagnostic efficacy of each needle in terms of sensitivity, specificity, positive and negative predictive value, and accuracy.

\section{Statistical analysis}

Continuous variables are expressed as medians and means, while categorical data are shown as frequencies and proportions. Fisher's exact test was used to assess the correlation between the diagnostic accuracy of each technique and McNemar's test to compare the proportion of suitable samples. The Wilcoxon test was used to analyze cellularity, bleeding, and histology. Cohen's kappa statistic was used to measure agreement between needles. $P$ values $\leq 0.05$ were considered significant with a $95 \%$ confidence interval. The sensitivity, specificity, positive and negative predictive values, and accuracy were calculated using standard definitions. The paired proportion test was used to compare the sensitivities and specificities of the needles.

\section{RESULTS}

A total of 64 patients were referred for EUS between December 2017 and April 2018. Of these, 20 met the eligibility criteria and were included in the study. The demographic, clinical, and imaging data are shown in Table 1 . The EUS showed that the pancreatic lesions were a mean $37 \pm 19 \mathrm{~mm}$ in the largest diameters and 11 were Doppler-negative masses. Qualitative elastography showed four soft tumors, seven intermediate tumors, and nine hard masses. Two patients were diagnosed with metastatic disease after the EUS assessment. Regarding the subjective classification of the number of collected specimens and the technical difficulty during the punctures, the 20G FNB needle provided a better impression of "increased material" compared to the $22 \mathrm{G}$ FNA needle $(p<0.001)$ with a similar difficulty profile (Table 2 )

The histopathological assessment showed that the mean diameter of the largest sample was $1.51 \pm 1.3 \mathrm{~mm}$ and $0.94 \pm 0.55 \mathrm{~mm}$ for the 20G FNB and 22G FNA needles, respectively $(p=0.032)$. The FNB needle allowed the collection of larger samples ( $6.3 \mathrm{~mm}$ wide). Figure 1 shows a histological comparison of the largest sample for the same patient with the different needles.

The number of cases with $>200$ diagnostic cells was higher for the 20G FNB needle than the 22G FNA needle ( $p=0.002$ ). Consequently, the FNB provided more suitable samples than the FNA (16 vs. 9, $p=0.039)$. There were no differences in terms of bleeding based on the worst score for each needle $(p=0.655)$. Table 3 summarizes the histopathological findings.
TABLE 1 - Demographic, clinical, and imaging data of 20 patients who underwent pancreatic solid lesion puncture using endosonography

\begin{tabular}{|l|c|}
\hline Age (years) & $64.7 \pm 12.5$ \\
\hline Gender & \\
\hline M & $9(45 \%)$ \\
\hline F & $11(55 \%)$ \\
\hline Clinical history of cancer & \\
\hline Colorectal & $2(10 \%)$ \\
\hline Kidney & $1(5 \%)$ \\
\hline Uterus & $1(5 \%)$ \\
\hline Symptoms & \\
\hline Abdominal pain & $14(70 \%)$ \\
\hline Weight loss & $12(60 \%)$ \\
\hline Lower back pain & $9(45 \%)$ \\
\hline Jaundice & $8(40 \%)$ \\
\hline Nausea/vomiting & $5(25 \%)$ \\
\hline Diarrhea & $2(10 \%)$ \\
\hline Imaging findings (CT/MRI) & \\
\hline Hypovascular & $12(60 \%)$ \\
\hline Hypervascular & $6(30 \%)$ \\
\hline Isovascular & $2(10 \%)$ \\
\hline Contours & \\
\hline \multicolumn{1}{|c|}{ Smooth } & $11(55 \%)$ \\
\hline Irregular & $9(45 \%)$ \\
\hline Location & \\
\hline Head & $12(60 \%)$ \\
\hline Body & $6(30 \%)$ \\
\hline Tail & $2(10 \%)$ \\
\hline Ascending MPD dilation & $3.81 \pm 2.18$ \\
\hline Distal atrophy & $12(60 \%)$ \\
\hline
\end{tabular}

$\mathrm{cm}=$ centimeter; $\mathrm{CT}=$ computed tomography; $\mathrm{F}=$ female; $\mathrm{M}=$ male; $\mathrm{MPD}=$ main pancreatic duct; $\mathrm{MRI}=$ magnetic resonance

TABLE 2 - Endosonographer's impression of the amount of procured tissue and technical difficulty during puncture according to the needle employed

\begin{tabular}{|c|c|c|c|c|c|c|}
\hline & & \multicolumn{4}{|c|}{ Needle } & \multirow{3}{*}{$\mathrm{p}^{*}$} \\
\hline & & \multicolumn{2}{|c|}{ 22G FNA } & \multicolumn{2}{|c|}{ 20G FNB } & \\
\hline & & $\mathrm{n}$ & $\%$ & $\mathrm{n}$ & $\%$ & \\
\hline \multirow{3}{*}{$\begin{array}{l}\text { Procured } \\
\text { specimen }\end{array}$} & Low & 3 & 15 & 0 & 0 & \multirow{3}{*}{$<0.001$} \\
\hline & Moderate & 15 & 75 & 2 & 10 & \\
\hline & Augmented & 2 & 10 & 18 & 90 & \\
\hline \multirow{4}{*}{$\begin{array}{l}\text { Technical } \\
\text { difficulty }\end{array}$} & None & 15 & 75 & 11 & 55 & \multirow{4}{*}{0.323} \\
\hline & Easy & 3 & 15 & 6 & 30 & \\
\hline & Intermediate & 1 & 5 & 1 & & \\
\hline & Hard & 1 & 5 & 2 & 10 & \\
\hline
\end{tabular}

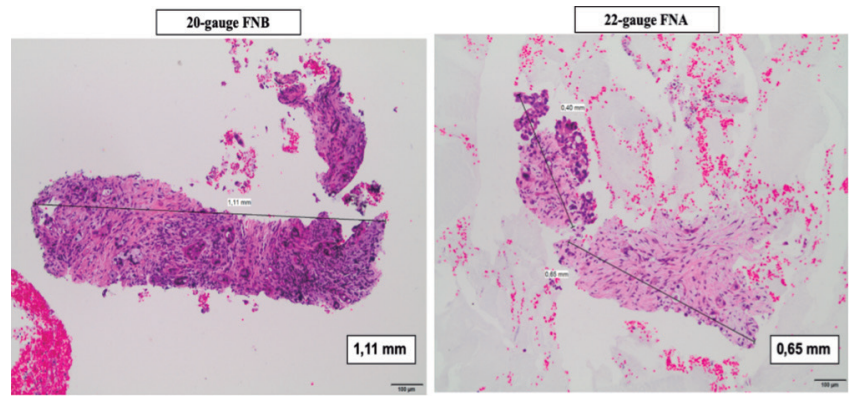

FNA=fine needle aspiration; FNB=fine needle biopsy

FIGURE 1 - Histological specimens from the same patient with the 20-gauge FNB needle (left) vs. the 22-gauge FNA needle (right, H\&Ex100) 
TABLE 3 - Comparison of needles in terms of best cellularity and worst bleeding

\begin{tabular}{|c|c|c|c|c|c|}
\hline \multirow[b]{3}{*}{ Cellularity } & \multicolumn{4}{|c|}{ Needle } & \multirow{3}{*}{$p^{*}$} \\
\hline & \multicolumn{2}{|c|}{ 22G FNA } & \multicolumn{2}{|c|}{ 20G FNB } & \\
\hline & $\mathrm{n}$ & $\%$ & $\mathrm{n}$ & $\%$ & \\
\hline$<50$ diagnostic cells & 6 & 30 & 0 & 0 & 0.002 \\
\hline 50-100 diagnostic cells & 5 & 25 & 4 & 20 & \\
\hline $100-200$ diagnostic cells & 4 & 20 & 5 & 25 & \\
\hline >200 diagnostic cells & 5 & 25 & 11 & 55 & \\
\hline Bleeding & $\mathrm{n}$ & $\%$ & $\mathrm{n}$ & $\%$ & $p^{*}$ \\
\hline Low & 6 & 30 & 6 & 30 & 0.655 \\
\hline Moderate & 14 & 70 & 13 & 65 & \\
\hline Severe & 0 & 0 & 1 & 5 & \\
\hline
\end{tabular}

Only one sample had no cells for diagnosis using the FNA needle, which was considered technical failure. A total of 14 and 16 cases had a positive diagnosis of malignancy with the $22 \mathrm{G}$ FNA and 20G FNB needles, respectively $(p=0.50)$. Later, 18 cases were confirmed positive during follow-up or surgery, indicating a sensitivity of $77.8 \%$ and $88.9 \%$ for the 22G FNA and 20 G FNB needles, respectively. On the paired proportions test, there were no differences in needle sensitivity $(p=0.36)$. There were no false positives for malignancy. The two true negative cases were diagnosed with autoimmune pancreatitis $(n=1)$ and serous microcystic adenoma $(n=1)$. The accuracy rates were $78.9 \%$ and $90 \%$ for the 22G FNA and 20G FNB needles, respectively. It was impossible to statistically compare the accuracy due to technical failure of the FNA group as the number of cases analyzed differed between them (19 vs. 20). The agreement between needles was 0.699 , indicating good reliability (Table 4).

TABLE 4 - Diagnostic efficiency of the 20-gauge FNB needle and the 22-gauge FNA needle

\begin{tabular}{|c|c|c|c|c|c|c|}
\hline Needle & Sensitivity & Specificity & PPV & NPV & Accuracy & Kappa \\
\hline 22G FNA & 77.8 & 100.0 & 100.0 & 20.0 & 78.9 & 0.689 \\
\hline 20G FNB & 88.9 & 100.0 & 100.0 & 50.0 & 90.0 & \\
\hline
\end{tabular}

$\mathrm{FNA}=$ fine needle aspiration; $\mathrm{FNB}=$ fine needle biopsy; $\mathrm{NPV}=$ negative predictive value; $\mathrm{PPV}=$ positive predictive value

Two self-limited bleeds that did not require intervention were reported after the end of the last puncture; therefore, it was impossible to determine which needle caused the bleeding. No late or serious AEs occurred.

Of the 18 positive cases of malignancy, 10 died of pancreatic disease, three underwent palliative chemotherapy, one to neoadjuvant chemotherapy (imatinib for gastrointestinal stromal tumor), and two stopped follow-up after the detection of metastatic disease. There were also two cases of grade 1 pancreatic neuroendocrine tumors: one patient underwent surgical resection confirming G1 PNET and the other was being clinically followed up.

\section{DISCUSSION}

This is the first controlled study to compare the new ProCore 20G FNB with the conventional 22G FNA fine needle for the diagnosis of pancreatic solid tumors. Previous studies compared the old ProCore $20 \mathrm{G}$ reverse-bevel FNB with the thinnest needle (25G FNA) available ${ }^{33}$ or reported data from uncontrolled studies ${ }^{2,6,15}$.

A recent study showed that the ProCore double forwardbevel needle has better performance than the previous generation ${ }^{6}$. Therefore, this new ProCore $20 \mathrm{G}$ device will soon replace the firstgeneration devices, which supports the assessment of its ability to obtain histological samples and achieve diagnostic accuracy.

The comparison between the use of the slow traction stylet and suction using the ProCore $20 \mathrm{G}$ needle showed that the two techniques have equivalent blood contamination and diagnostic accuracy ${ }^{11}$. A retrospective multicenter study showed that this needle achieved an $88 \%$ correct histological diagnosis rate for 50 subepithelial lesions ${ }^{4}$. The $85 \%$ sensitivity was greater than that of standard FNA ${ }^{12}$. This comparison of the 22G FNB needle (Acquire ${ }^{\circledR}$, Boston Scientific) and the ProCore 20G showed similar diagnostic results except for the greater mean length of the histological nucleus per needle pass, which favored the $22 \mathrm{G}^{22}$. Those reports have all currently available data regarding the performance of the ProCore $20 \mathrm{G}$ needle; therefore, the present study retrospectively contributed to the overall findings and provides new results with greater evidence.

It was technically possible to perform EUS-guided puncture in all cases in the present study, in contrast to the $10 \%$ rate of technical failure due to the rigidity of the $20 \mathrm{G}$ needle that was reported in a recent work ${ }^{22}$. The only technical failure occurred with the 22G FNA needle and was detected during the microscopic examination. Therefore, there were no differences in the present study between needles regarding puncture difficulty, and the technical failure outcome may be associated with other factors such as lesion stiffness and location rather than the device used for the puncture.

In addition to these difficulties, theendoscopistalso subjectively classified the tissue amount. The 20G FNB provided significantly more samples classified macroscopically as suitable material. Although this can result from the caliber difference, it can also indicate that the FNB has an increased capacity to collect larger tissue samples. The histological assessment confirmed the latter hypothesis from two different perspectives: the mean sample size was significantly larger and the FNB provided more adequate samples than the 22G FNA needle.

On the other hand, the histological findings showed no differences in sensitivity. There are two hypotheses to explain this fact. First, the pathologist (MOB) is experienced and familiar with examining pancreatic lesions, which possibly improves the sensitivity of the puncture with the 22G FNA needle, thus reducing the difference between the needles. However, this result can change from favoring the ProCore 20G FNB in centers with less experienced pathologists or those with general training. Additionally, this study had a small sample, which may have impaired our ability to identify an even greater difference.

Although it was impossible to show a statistical difference, other results, such as tissue adequacy, cellularity scores, and mean length of histological nucleus, were better with the ProCore 20G FNB and provided the pathologist with general training with suitable and representative histological material in addition to supporting additional molecular studies.

This assessment was reinforced in a recent study that collected samples using the FNB. In addition to greater diagnostic precision, there was greater agreement in the diagnosis of malignancy between academic and non-academic pathologists ${ }^{32}$. This information indirectly suggests that the ProCore 20G FNB provides greater confidence in the diagnosis of malignancy, especially for pathologists with general training, but this should be further studied.

It was difficult to separate the histological nucleus in samples collected with the ProCore 20 G FNB needle, which can be associated with hypothetical failure resulting from intervening vessel injury. However, in the present study, there were no significant differences in bleeding of the samples collected by the two studied needles.

Regarding AEs, 2 cases of bleeding (10\%) were reported, a rate that is higher than the mean reported rate of $0-2.9 \% \%^{6,11,15}$, and could indeed be associated with the characteristics of the ProCore 20G FNB in addition to the four punctures of each patient. Although the rate was high, the bleeding was self-limited and did not require any additional aggressive intervention.

Due to the technical failure of the 22G FNA, it was impossible to perform a statistical analysis to compare the accuracies of the needles, but the results of this study agree with those in the literature, which showed a better performance of the new ProCore $20 \mathrm{G}$ compared to the standard needle used in uncontrolled assessments ${ }^{3}$. Moreover, comparison of the 19G FNA needle 
with several other FNB needle models with the same caliber for the diagnosis of solid injuries showed an overall accuracy of $79 \%$ vs. $90 \%(p=0.039)$ for the 19G FNA and 19G FNB needles, respectively ${ }^{20}$. These results are like those reported in the present study, which suggests that a significant difference is possible in numerically comparable samples.

\section{CONCLUSION}

The new ProCore 20G FNB double forward-bevel needle provided more adequate tissue samples with better cellularity scores and larger mean histological nucleus size without increasing puncture difficulty and bleeding episodes compared to the $22 \mathrm{G}$ FNA needle. Although there were no differences in diagnostic accuracy between the devices, the characteristics of the samples collected with the ProCore 20G FNB can favor centers with less experienced pathologists.

\section{REFERENCES}

1. Abdelgawwad MS, Alston E, Eltoum IA. The frequency and cancer risk associated with the atypical cytologic diagnostic category in endoscopic ultrasound-guided fine-needle aspiration specimens of solid pancreatic lesions:ameta-analysisandargumentforaBethesdaSystemforReporting Cytopathology of the Pancreas. Cancer Cytopathol. 2013;121:620-628.

2. Alatawi A, Beuvon F, Grabar S, et al. Comparison of $22 \mathrm{G}$ reverse-beveled versus standard needle for endoscopic ultrasound-guided sampling of solid pancreatic lesions. United Eur Gastroenterol J. 2015;3:343-352.

3. Ang $T L$, Li JW, Kwek $A B E$, et al. The difference in histological yield between 19GEUS-FNAand EUS-fine-needlebiopsyneedles. Endoscopic Ultrasound. 2019;8:255-260

4. Antonini F, Delconte G, Fuccio L et al. EUS-guided tissue sampling with a 20-gauge core biopsy needle for the characterization of gastrointestinal subepithelial lesions: a multicenter study. Endoscopic Ultrasound. 2019:8:105-110.

5. Ardengh JC, Lopes CV, de Lima LFP, et al. Cell block technique and cytological smears for the differential diagnosis of pancreatic neoplasms afterendosonography-guided fine-needleaspiration.ActaGastroenterol Latinoamericana. 2008;38:246-251.

6. Armellini E, Manfrin E, Trisolini $\mathrm{E}$, et al. Histologic retrieval rate of a newly designed side-bevelled 20G needle for EUS-guided tissue acquisition of solid pancreatic lesions. United Eur Gastroenterol J. 2019;7:96-104.

7. Asokkumar R, Yung KaC, Loh T, etal. Comparison of tissue and molecula yield between fine-needlebiopsy(FNB) and fine-needleaspiration(FNA): a randomized study. Endosc Intl Open. 2019;7:E955-963.

8. BELOTTO, Marcos et al. PANCREATIC NEUROENDOCRINE TUMORS SURGICAL RESECTION. ABCD, arq. bras. cir. dig., 2019, vol.32, no.1. ISSN 0102-6720

9. Cheng B, Zhang Y, Chen Q, et al. Analysis of fine-needle biopsy vs fineneedle aspiration in diagnosis of pancreatic and abdominal masses: a prospective, multicenter, randomized controlled trial. Clin Gastroenterol Hepatol. 2018;16:1314-1321.

10. Cheng S, Brunaldi VO, Minata MK, et al. Suction versus slow-pull for endoscopicultrasound-guidedfine-needleaspiration of pancreatictumors: a prospective randomized trial. HPB [Internet]. 2019; Available from: http://www.sciencedirect.com/science/article/pii/S1365182X19307385.

11. Di Mitri R, Mocciaro F, Antonini F, et al. Stylet slow-pull vs. standard suction technique for endoscopic ultrasound-guided fine needle biopsy in pancreatic solid lesions using 20 Gauge Procore needle: a multicenter randomized trial. Dig Liver Dis. 2020 Feb;52(2):178-184.

12. Facciorusso A, Sunny SP, Del Prete V, et al. Comparison between fineneedle biopsy and fine-needle aspiration for EUS-guided sampling of subepithelial lesions: a meta-analysis. Gastrointest Endosc. 2020 Jan;91(1):14-22.e2.

13. Facciorusso A, WaniS, TriantafyllouK, etal.Comparativeaccuracy ofneedle sizes and designs for EUS tissue sampling of solid pancreatic masses: a networkmeta-analysis. GastrointestEndosc.2019Dec:90(6):893-903.e7.

14. Fisher L, Segarajasingam DS, Stewart C, et al. Endoscopic ultrasound guided fine needle aspiration of solid pancreatic lesions: Performance and outcomes. J Gastroenterol Hepatol. 2009;24:90-96.

15. Fujie S, Ishiwatari H, Sasaki K, et al. Comparison of the Diagnostic yield of the standard 22-gauge needle and the new 20-gauge forward-bevel core biopsy needle for endoscopic ultrasound-guided tissue acquisition from pancreatic lesions. Gut Liver. 2019;13:349-355.

16. GleesonFC,KippBR,CaudillJL, etal.Falsepositiveendoscopicultrasoundfine needleaspiration cytology:incidenceandriskfactors. Gut.2010;59:586-593.
17. Hikichi T, Irisawa A, Bhutani MS, et al. Endoscopic ultrasound-guided fine-needle aspiration of solid pancreatic masses with rapid on-site cytological evaluation by endosonographers without attendance of cytopathologists. J Gastroenterol. 2009;44:322-328.

18. Imai K, Matsubayashi H, Fukutomi A, et al. Endoscopic ultrasonographyguided fine needleaspiration biopsy using 22-gauge needle in diagnosis of autoimmune pancreatitis. Dig Liver Dis. 2011;43:869-874.

19. Itoi T, Tsuchiya T, Itokawa F, et al. Histological diagnosis by EUS-guided fine-needle aspiration biopsy in pancreatic solid masses without on-site cytopathologist: a single-center experience. Dig Endosc. 2011;23:34-38

20. Iwashita T, Nakai Y, Mukai T, et al. A 19-gauge histology needle versus a 19-gaugestandard needleinendoscopicultrasound-guided fine-needle aspiration for solid lesions: a multicenter randomized comparison study (GREATER Study). Dig Dis Sci. 2018;63:1043-1051.

21. Iwashita T, Nakai Y, Samarasena JB, et al. High single-pass diagnostic yield of a new 25-gauge core biopsy needle for EUS-guided FNA biopsy in solid pancreatic lesions. Gastrointest Endosc. 2013;77:909-915.

22. KarsentiD, TharsisG,ZeitounJ-D, etal.Comparison of20-gaugeProcore(R) and 22-gauge Acquire(R) needles for EUS-FNB of solid pancreatic masses: an observational study. Scand J Gastroenterol. 2019;54:499-505.

23. Kudo T, Kawakami H, Hayashi T, et al. High and low negative pressure suction techniques inEUS-guided fine-needle tissueacquisition by using 25-gauge needles: a multicenter, prospective, randomized, controlled trial. Gastrointest Endosc. 2014;80:1030-1037.

24. Lee JK, Choi JH, Lee KH, et al. A prospective, comparative trial to optimize sampling techniques in EUS-guided FNA of solid pancreatic masses. Gastrointest Endosc. 2013:77:745-751.

25. Matsubayashi H, Matsui T, YabuuchiY, etal. Endoscopicultrasonography guided-fineneedleaspiration forthediagnosis ofsolid pancreaticobiliary lesions: Clinical aspects to improve the diagnosis. World J Gastroenterol. 2016; 22:628-640.

26. NakaiY, Isayama H, Chang KJ, etal. Slow pull versus suction in endoscopic ultrasound-guided fine needle aspiration of pancreatic solid masses. Dig Dis Sci 2014 Jul; 59(7):1578-85.

27. NavinaS,McGrathK, ChennatJ, etal.Adequacyassessmentofendoscopic ultrasound-guided, fine-needle aspirations of pancreatic masses for theranostic studies: optimization of current practices is warranted. Arch Pathol Lab Med. 2014:138:923-928.

28. REZENDE,AchilesQueirozdeMonteiroetal.PANCREATICODUODENECTOMY IMPACTOFTHETECHNIQUEONOPERATIVEOUTCOMESANDSURGICAL MORTALITY. ABCD, arq. bras. cir. dig. 2019, vol.32, no.1. ISSN 0102-6720

29. Ryozawa S, Kitoh H, Gondo T, et al. Usefulness of endoscopicultrasoundguided fine-needle aspiration biopsy for the diagnosis of pancreatic cancer. J Gastroenterol. 2005;40:907-911.

30. SuzukiR, IrisawaA, Bhutani MS, etal.Prospectiveevaluation oftheoptimal number of 25-gauge needle passes for endoscopic ultrasound-guided fine needle aspiration biopsy of solid pancreatic lesions in the absence of an onsite cytopathologist. Dig Endosc. 2012;24:452-456.

31. UrbaniakGC,PlousS.2013. Research Randomizer(Version4.0) [Computer software]. Retrieved on Jan 06, 2020, from http://www.randomizer.org.

32. van Riet PA, Cahen DL, Biermann K, et al. Agreement on endoscopic ultrasonography-guided tissuespecimens:comparinga20-Gfine-needle biopsy to a 25-G fine-needle aspiration needle among academic and non-academic pathologists. Dig Endoscopy. 2019; :

33. van Riet PA, Larghi A, Attili F, et al. A multicenter randomized trial comparinga25-gaugeEUSfine-needleaspiration devicewitha20-gauge EUSfine-needlebiopsydevice. GastrointestEndoscop. 2019;89:329-339.

34. Volmar KE, Vollmer RT, Jowell PS, Nelson RC, Xie HB. Pancreatic FNA in 1000 cases: a comparison of imaging modalities. Gastrointest Endosc. 2005:61:854-861.

35. Wyse JM, Paquin SC, Joseph L, et al. EUS-FNA without the stylet: The yield is comparable to that with the stylet and sampling of multiple sites during the same pass may improve samplequality and yield. Gastrointest Endosc. 2009;69:AB330-331. 